Syracuse University

SURFACE

Summer 7-24-2012

\title{
The President and the Autopen: It Is Unconstitutional for Someone or Something to Sign a Bill Outside of the President's Presence
}

Terry L. Turnipseed

Syracuse University College of Law, tlturnip@law.syr.edu

Follow this and additional works at: https://surface.syr.edu/lawpub

Part of the Law Commons

\section{Recommended Citation}

Turnipseed, Terry L., "The President and the Autopen: It Is Unconstitutional for Someone or Something to Sign a Bill Outside of the President's Presence" (2012). College of Law - Faculty Scholarship. 83.

https://surface.syr.edu/lawpub/83

This Article is brought to you for free and open access by the College of Law at SURFACE. It has been accepted for inclusion in College of Law - Faculty Scholarship by an authorized administrator of SURFACE. For more information, please contact surface@syr.edu. 


\title{
THE PRESIDENT AND THE AUTOPEN: IT IS UNCONSITUTIONAL FOR SOMEONE OR SOMETHING TO SIGN A BILL OUTSIDE OF THE PRESIDENT'S PRESENCE
}

\author{
TERRY L. TURNIPSEED*
}

We are in danger of forgetting that a strong public desire to improve the public condition is not enough to warrant achieving the desire by a shorter cut than the constitutional way ...

\section{ABSTRACT}

On May 26, 2011, only hours before three provisions of the Foreign Intelligence Surveillance Act were scheduled to expire, Congress passed an extension. For days, the White House had someone ready to fly to Europe with the legislation in hand for the President to sign, but Congress had been tardy. It seemed quite important to the White House that none of these provisions lapse for any length of time, even the relatively short time it would take to fly from Washington to France. With this urgency as a backdrop, the President was awakened at 5:45 a.m. Central European Time so he could authorize a first: phone a White House staffer in Washington, D.C., and instruct him to use an autopen to sign the bill. No President had ever had anyone else sign on his behalf, and certainly no President had ever ordered the use of an autopen to inscribe his signature on a bill when away from the White House.

This Article explores multiple facets of the President's use of a proxy signature to sign legislation.

The state of the law surrounding proxy signatures has remained amazingly constant through both English and American history. The proxy and the principal must be present together when a proxy signature is utilized

\footnotetext{
" Terry L. Turnipseed, J.D., LL.M., Georgetown University Law Center; M.S., Nuclear Engineering, M.S., Technology \& Policy, Massachusetts Institute of Technology; B.S., Nuclear Engineering, Mississippi State University. Thanks to Tara Helfman for her exceptionally valuable contributions to this Article, and without whom this Article would not have been possible. Thanks also to Keith Bybee for his important comments on the manuscript, and to my wonderful research assistant Sherry Conaway.

${ }^{1}$ Pennsylvania Coal Co. v. Mahon, 260 U.S. 393, 416 (1922) (Holmes, J.).
} 
for a high-value transaction. This was the rock-solid law when the constitution was written.

No one seems focused on the presence requirement: not the President, nor the Republican House members who complained to the President, nor the numerous legal commentators and scholars that we have heard from since the autopen signing occurred. The use of the autopen, itself unproblematic, seems to have eclipsed the more important issue of whether the president was present when it was used.

By definition, if a non-presence proxy signature is affixed to a bill, then time is of the essence. When time is of the essence, the consequences of a voided signature are never greater. Since the President has roughly twelve days to sign a bill, a non-presence proxy signature could produce one of two unintended consequences. At best, it would produce a twelve-day period during which the new legislation would not be in effect. At worst, if Congress is not in session at the end of the twelve-day period, it would amount to a pocket veto. Neither case is consistent with well-ordered government.

In sum, the President's use of the autopen (or even a human being) to sign a bill outside of the President's presence is unconstitutional. This establishes a dangerous precedent, one which every thinking lawyer in Washington politics seemed to have overlooked. Let the autopen episode not be a precedent for this or any other President to follow. The Constitution does not allow for shortcuts.

\section{INTRODUCTION}

On May 26, 2011, only hours before three provisions of the Foreign Intelligence Surveillance Act ("FISA") were scheduled to expire, Congress passed an extension. ${ }^{2}$ For days, the White House had someone ready to fly to Europe with the legislation in hand for the President to sign, but Congress had been tardy. ${ }^{3}$ It seemed quite important to the White House that none of these provisions lapse for any length of time, even the relatively short time it would take to fly from Washington to France. ${ }^{4}$ With this urgency as a backdrop, the President was awakened at 5:45 a.m. Central European Time so he could authorize a first: phone a White House staffer in Washington, D.C., and instruct him to use an autopen to sign the bill. No President had ever had anyone else sign on his behalf, and certainly no President had ever

\footnotetext{
${ }^{2}$ S. 990, The Patriot Sunsets Extensions Act of 2011.

3 Obama Uses Autopen to Sign the Patriot Act Extension, New York Times (May 27, 2011) [hereinafter New York Times].

${ }^{4}$ It is not clear to the author why this is so since all three expiring FISA provisions had grandfathering language anticipation a lapse that provided for the continuation of the applicability of the provisions to ongoing investigations during any lapse. This is discussed in more detail in Part IV of this Article.
} 
ordered the use of an autopen ${ }^{5}$ to inscribe his signature on a bill when away from the White House. The use of the autopen was quite a radical departure from the norm.

This Article explores multiple facets of the President's use of a proxy signature to sign legislation. In particular, the house-of-cards 2005 Office of Legal Counsel's memorandum to President George W. Bush making the legal case for the use of a non-presence proxy to sign bills (the "Nielson Memorandum") $)^{6}$ will be critiqued. It is worth noting that despite this opinion President Bush never utilized a proxy to sign a bill. ${ }^{7}$ In 2005 , in fact, President Bush flew through the night to get to the White House in time to sign the Terri Schiavo bill. ${ }^{8}$ This practice continued into President Obama's tenure, including a December 2010 hurried flight by a White House staffer to Hawaii, where the President was vacationing, to obtain the President's in-person signature on the September $11^{\text {th }}$ responders bill. ${ }^{9}$

The use of the autopen to sign a bill into law brought swift criticism from 21 House members in the form of a strongly-worded letter to the President that reiterated the multiple dissenting opinions detailed in the Nielson Memorandum. ${ }^{10}$ It has also produced some good-natured humor. ${ }^{11}$

\footnotetext{
5 Mechanical handwriting reproduction devices are nothing new. Indeed just such a device was patented in 1803, with Thomas Jefferson using one (and improving it). Jefferson researched and wrote letters in what has been called the earliest modern office. Jefferson's Cabinet had a revolving bookstand, table, and chair. Here Jefferson used a copying machine to make duplicate sets of his letters. Drudging at the Writing Table, The Jefferson Monticello (Aug. 8, 2011), http://www.monticello.org/site/jefferson/drudging-writing-table.

${ }^{6}$ Memorandum from Howard C. Nielson, Jr., Deputy Assistant Attorney General, Office of Legal Counsel, Re: Whether the President May Sign a Bill by Directing That His Signature be Affixed to It (July 7, 2005) [hereinafter Nielson Memorandum].

${ }^{7}$ New York Times, supra note 3. George W. Bush thought about a test case - using the autopen to sign a minor bill into law - "but in the end Bush just kept signing the parchment himself" said Ari Fleischer, the former White House press secretary. White House Remains Mum on Use of Autopen to Sign Legislation, Associated Press (June 26, 2011) (http://www.foxnews.com/politics/2011/06/26/white-house-remains-mum-on-useautopen-to-sign-legislation/\#ixzz1Re1N968S).

${ }^{8}$ New York Times, supra note 3.

${ }^{9}$ Id.

${ }^{10}$ Some of the text of this letter follows. The remainder of the letter - Nielson Memorandum cites that quote prior dissenting opinions - is detailed in Part III.
}

Mr. President:

On May 26, 2011, the United States Senate and House of Representatives passed S. 990, the "PATRIOT Sunsets Extensions Act of 2011." Shortly before midnight, the White House press secretary released a statement that you signed the bill into law.

However, your Administration later confirmed that you authorized the use of an autopen to sign S. 990. Mr. President, your use of the autopen appears contrary to the Constitution. 
Article I, section 7 of the United States Constitution states:

"Every bill which shall have passed the House of Representatives and the Senate, shall, before it becomes a Law, be presented to the President of the United States; If he approve he shall sign it, but if not he shall return it ..."

On May 27, 2011, Congressman Tom Graves wrote you to request an explanation for your Constitutional authority to assign a surrogate the responsibility of signing bills passed by Congress into law. As of today, Congressman Graves has yet to receive a response from the White House.

While the July 7, 2005, opinion of the Office of Legal Counsel (OLC) to President George W. Bush on using a surrogate to sign bills into law was apparently the basis for your decision, we are compelled to point out that the memorandum provides a long list of dissenting opinions. On pages 25-26, the OLC memorandum cites the following: [these cites are presented in Part III, infra]

Despite the 2005 opinion of the OLC, neither President George W. Bush nor any of your predecessors assigned a surrogate, or autopen, to sign a bill into law.

Mr. President, it is clear that assigning a surrogate the responsibility of signing bills passed by Congress is a debatable issue, and could be challenged in court. That being the case, our request is that, out of an abundance of caution, you affix your signature to S. 990 by personally re-signing the enrolled bill. We recall you retaking the Oath of Office on January 21, 2009, over similar concerns for adhering to the Constitution, and believe your signing legislation passed by the United States Congress is of equal importance. Furthermore, we ask that you commit to ending the practice of using an auto pen to sign bills passed by Congress.

Thank you for your consideration of this matter. We look forward to your response.

June 17, 2011

Available at

http://www.cbsnews.com/htdocs/pdf/AutopenLetter061711a.pdf?tag=contentMain;conte ntBody [hereinafter House Letter].

Note that the letter calls for President Obama to sign the legislation now. Of course this would have no effect since the bill is already a law due to the passage of the ten-day period (excluding Sundays), with that period ending at a time when Congress was in session. There was, however, a twelve-day period when neither the old FISA provisions nor the renewed provisions were in force. See infra Part IV.

${ }^{11}$ See, e.g., Republicans Urge Autopen to Consider Presidential Campaign, The Huffington Post (May 28, 2011) (http://www.huffingtonpost.com/ben-ritz/obamaautopen-_b_868371.html): 
In Part I, this Article details the constitutional underpinnings of the Presidential signature requirement. Part II of this Article discusses the origins of proxy signatures, and in particular the associated presence requirement for proxy signatures. The origins date back to the Statute of Frauds and then the Statute of Wills. As the starting point for analysis of proxy signatures generally, the longstanding and extensive body of law associated with proxy signatures for wills is the most important lens to view the requirements for Presidential proxy signatures. Part II, then, explores in detail the law of will proxy signatures that forms the bedrock of interpreting the Article I $\$ 7$ Presidential signature requirement. Part III critiques the Nielson Memorandum's treatment of the presence requirement for proxy signatures. This critique includes a look at the Nielson Memorandum's cites to the lessons of will executions that require the proxy to be present, though the memorandum ignores these same lessons in a shoddy attempt to explain away the presence requirement in a footnote. Part IV examines potential negative consequences that could flow from a void Presidential signature on a bill. Finally, Part V concludes.

The recent focus on the Autopen now has Republicans developing a new game plan for the 2012 election. With their field of viable prospective presidential candidates rapidly shrinking, many Republican insiders have quietly begun urging the Autopen to mount a bid for the GOP Presidential nomination to unseat President Obama. Despite having never itself served as an elected representative, the autopen has worked under nearly every politician in the United States since 1946, signing countless letters to constituents and prospective political supporters. The Autopen, they say, is uniquely qualified to run a strong campaign and already has a leg up on a majority of the declared contenders.

"Mr. Pen already has more experience in government than Herman Cain, who himself is inexplicably polling at 8 percent of Republican primary voters," said conservative columnist Charles Krauthammer. "Unlike Newt Gingrich, it doesn't have problems keeping its message consistent, and although it may not have the people skills that Mr. Obama possesses, its charisma far exceeds that of Tim Pawlenty."

"The Autopen is the best serious candidate we can come up with now that both Governors Chris Christie and Mitch Daniels have declined to run," says a Republican National Committee member who asked to speak off the record. He observed that the Autopen has quickly gained support among establishment Republican officials afraid that the renewed prospect of a Palin run could sink their chances of retaking the White House. "The fact is, Governor Palin just doesn't have the intellectual curiosity that the Autopen possesses. Most of us have personally worked with both Ms. Palin and the Autopen and we all believe that when it comes time to make the hard decisions and answer the tough questions, Sarah Palin cannot match the Autopen's skills." 
In sum, the President's use of the autopen (or even a human being) to sign a bill outside of the President's presence is unconstitutional. ${ }^{\text {I2 }}$ This establishes a dangerous precedent, one which every thinking lawyer in Washington politics seemed to have overlooked.

\section{The Constitution}

The Supreme Court has not extensively considered the fundamental significance of the President's signature under Article $1, \S 7$ clause $2 .^{13}$ It is hard to believe that, after more than two hundred years of constitutional construction, an act so essential to one of the most routine functions of government, lawmaking, has escaped the scrutiny of the federal courts. This is, perhaps, because it has long been taken for granted that the President's signature is more than a perfunctory mark of approval. As discussed in the introduction above, President Obama's use of the autopen to renew three provisions of FISA in absentia is without precedent in American history. But it is not the President's use of the autopen that is problematic. Rather, the President's absence during the proxy signing is, and it demands an examination of the very nature of the Constitution's signature requirement.

Art. I, §7, cl. 2 reads, in relevant part, as follows:

Every Bill which shall have passed the House of Representatives and the Senate, shall, before it become a Law, be presented to the President of the United States: If he approve he shall sign it, but if not he shall return it, with his Objections to that House in which it shall have originated ... If after such Reconsideration two thirds of that House shall agree to pass the Bill, it shall be sent, together with the Objections, to the other House, by which it shall likewise be reconsidered, and if approved by two thirds of that House, it shall become a Law ... . If any Bill shall not be returned by the President within ten Days (Sundays excepted) after it shall have been presented to

\footnotetext{
${ }^{12}$ Of course, just as in the analogous large body of statutory and case law for wills, the President could have a proxy sign a bill while in the President's presence. Otherwise, for example, we could not have a functional physically-challenged President who was unable to sign. Also in accord with the law of the execution of wills, the President need not have a physical challenge in order to utilize a proxy who signs in his or her presence.

${ }^{13}$ It has, however, ruled on the timeliness of the President's signature (La Abra Silver Mining Case Co. v. United States, 175 U.S. 423 (1899) (under Art. 1, §7 the President may sign a bill into law during a Congressional recess); Edwards v. United States, 286 U.S. 482 (1932) (under Art., $1 \$ 7$ the President may sign a bill into law after the final adjournment of the Congress that passed and presented it)) and on the legal effect of the President's signature with respect to the line item veto (Clinton v. City of New York, 524 U.S. 417 (1998) (Line Item Veto Act violated the presentment clause of Art. 1, §7 and the separation of powers)).
} 
him, the Same shall be a Law, in like Manner as if he had signed it, unless the Congress by their Adjournment prevent its Return, in which Case it shall not be a Law.

It thus establishes three means by which a bill can become a law: (1) by the signature of the President; (2) by supermajority, and; (3) by the lapse of ten days (excluding Sundays) from presentment (assuming Congress is in session for the period), absent a veto and absent the signature of the President. $^{14}$

The debates on the Constitution provide indispensable guidance on the principles informing the signature requirement. ${ }^{15}$ Alexander Hamilton himself noted, "There is hardly any part of the system which could have been attended with greater difficulty in the arrangement of [the Constitution] than [the Executive]". ${ }^{16}$ The Supreme Court recently agreed, noting,

[t]he procedures governing the enactment of statutes set forth in the text of Article I were the product of the great debates and compromises that produced the Constitution itself. Familiar historical materials provide abundant support for the conclusion that the power to enact statutes may only be exercised in accord with a single, finely wrought and exhaustively considered, procedure. ${ }^{17}$

\footnotetext{
${ }^{14}$ John Quincy Adams explained that these three alternative methods of lawmaking were a product of the unique American constitutional system. Unlike Great Britain, where the institution of King-in-Parliament is alone competent to make laws, in the United States, "the principles [a]re different. . . . [T] he President is not a constituent part of Congress, and an Act of Congress may be valid as law without his signature or assent." MEMOIRS OF JOHN QUiNCY ADAMS (1875), vol. 6, p. 279. The framers explicitly rejected the model of King-in-Parliament, and with it a chief magistrate who would be, in Hamilton's words, "a hostage to the national justice for his good behavior. In the American republic it would serve to destroy, or would greatly diminish the intended and necessary responsibility of the chief magistrate himself." THE FEDERALIST NO. 70 at 346 (Terence Ball ed., 2006). In the American republic, a more vigorous presidency would be necessary.

${ }^{15}$ The Supreme Court has acknowledged the importance of the debates on constitutional interpretation. See e.g. Holmes v. Jennison, 39 U.S. 540, 570-71 (1840):
}

In expounding the Constitution of the United States, every word must have its due force, and appropriate meaning; for it is evident from the whole instrument, that no word was unnecessarily used, or needlessly added. The many discussions which have taken place upon the construction of the Constitution, have proved the correctness of this proposition; and shown the high talent, the caution, and the foresight of the illustrious men who framed it. Every word appears to have been weighed with the utmost deliberation, and its force and effect to have been fully understood.

16 The Federalist No. 67, at 327 (Terence Ball ed., 2006).

${ }^{17}$ Clinton v. New York, 524 U.S. at 439-40. 
The original lawmaking procedure considered by the Constitutional Convention contained no signature requirement at all. But then again, it also envisioned a decidedly weak Executive. ${ }^{18}$ The Randolph Propositions, which were the starting point for the Constitutional Convention, ${ }^{19}$ vested the power to make law in Congress, but conferred a veto power on a Council of Revision composed of the Executive (not yet defined as a unitary institution) "and a convenient number of the National Judiciary". ${ }^{20}$ But as successive drafts of the Constitution circulated, the signature requirement emerged in close connection with the development of the separation of powers doctrine. As James Madison explained to Convention delegates,

If it be essential to the preservation of liberty that the Legisl[ative,] Execut[ive,] and Judiciary powers be separate, it is essential to a maintenance of the separation that they should be made independent of each other. The Executive could not be independent of the Legislature, if dependent on the pleasure of that branch for a reappointment. . . In like manner a dependence of the Executive on the Legislature, would render it the Executor as well as the maker of laws; \& then according to the observation of Montesquieu, tyrannical laws may be made that they may be executed in a tyrannical manner. . . . . Experience had proved a tendency in our [state] governments to throw all power into the Legislative vortex. The Executives of the States are in general little more than Cyphers; the legislatures omnipotent. ${ }^{21}$

As the Convention began to debate an affirmative role for the Executive in the legislative process, a role that would make it more than a mere cypher of the Legislature, two versions of what would become Art. I, §7 circulated

\footnotetext{
${ }^{18}$ Of the original thirteen states, only Maryland's constitution required the Governor's signature in the legislative process. Even so, the Governor was required to sign a bill only after it had effectively passed into law. He had no veto power, and thus lacked the discretion to refuse to sign. Constitution of Maryland (1776) available at http://avalon.law.yale.edu/17th_century/ma02.asp ("Art. LX. That every bill passed by the General Assembly, when engrossed, shall be presented by the Speaker of the House of Delegates, in the Senate, to the Governor for the time being, who shall sign the same, and thereto affix the Great Seal, in the presence of the members of both Houses: every law shall be recorded in the General Court office of the western shore, and in due time printed, published, and certified under the Great Seal, to the several County Courts, in the same manner as hath been heretofore used in this State.")

19 Also known as the Virginia Plan, the Propositions were authored by James Madison and presented by Governor Edmund Randolph of Virginia, who memorably referred to a strong unitary Executive as "the foetus of monarchy." NOTES ON DEBATES IN THE FEDERAL CONVENTION OF 1787 REPORTED By JAMES MADISON 46 (1987).

${ }^{20}$ Notes on Debates in the Federal Convention of 1787 Reported by James MADISON 32 (1987).

${ }^{21} I$. at $311-12$.
} 
among the delegates. The first, put forward for consideration on August $6^{\text {th }}$ 1786, stipulated:

Every bill, which shall have passed the House of Representatives and the Senate, shall, before it become a law, be presented to the President of the United States for his revision: if, upon such revision, he approve of it, he shall signify his approbation by signing it: But if, upon such revision, it shall appear to him improper for being passed into a law, he shall return it, together with his objections against it, to that House in which it shall have originated, who shall enter the objections at large on their journal and proceed to reconsider that bill. . ${ }^{22}$

The second proposal, which Madison put before the Convention on August $15^{\text {th }}$, stipulated:

Every bill which shall have passed the two houses, shall, before it become a law, be severally presented to the President of the United States, and to the judges of the supreme court for the revision of each. If, upon such revision, they shall approve of it, they shall respectively signify their approbation by signing it; but if, upon such revision, it shall appear improper to either, or both, to be passed into a law, it shall be returned, with the objections against it, to that house, in which it shall have originated. . 23

Although the composition of the executive is different in each draft, early formulations of the presentment and signature requirements of Art. I, §7 appear in each. Moreover, the signature requirements in each draft share a common purpose: the President's signature is to serve as a formal act signifying the approval of the Executive.

The signature requirement can also be understood as a safeguard against the abuse of executive power. As James Iredell, leader of the North Carolina Federalists and future justice of the Supreme Court, explained, "the President must be personally responsible for every thing (emphasis in original)." ${ }^{24}$ A necessary means of ensuring such accountability was that all important advice and decisions be reduced to writing. ${ }^{25}$ Iredell's discussion

\footnotetext{
${ }^{22} I d$. at $388-89$.

${ }^{23} I d$. at 462.

24 James Iredell, Answers to Mason's "Objections" in I THE DEBATE ON THE Constitution (Bernard Bailyn ed., 377) (1990). Iredell was by no means alone in holding this view of the presidency. (See e.g. Tench Coxe, An American Citizen, in id., 23 ("the people have a strong hold upon [the President] from his sole and personal responsibility (emphasis in original.").

${ }^{25}$ Iredell, Answers to Mason's "Objections", at 376.
} 
of the role of the President's advisors is particularly illuminating in this respect:

[The President] is not to be assisted by a Council, summoned to a jovial dinner perhaps, and giving their opinions according to the nod of the President-but the opinion is to be given with the utmost solemnity, in writing. No after equivocation can explain it away. It must for ever after speak for itself, and commit the character of the writer, in lasting colours either of fame or infamy, or neutral significance, to future ages, as well as the present (emphasis in original).

Note that the writing requirement has two attributes: first, it must be public, and second, the writing is imputed to the writer himself. In this manner, Iredell explained, "the President who acts should be responsible for his conduct, following advice at his peril, than that there should be a danger of punishing any man for an erroneous opinion which might possibly be sincere (emphasis in original)., 26

Both the Constitution as ratified and its early drafts treat the acts of approval and signature as separate and distinct from one another. However, for a bill to become law by approval of the President, the President's signature is essential. The Supreme Court recognized this distinction in $L a$ Abra when it explained,

It has properly been the practice of the President to inform Congress by message of his approval of bills, so that the fact may be recorded. But the essential thing to be done in order that a bill may become law by the approval of the President is that it be signed within the prescribed time after being presented to him. ${ }^{27}$

If Presidential approval alone were enough to turn a bill into a law, it would be sufficient for the President to inform Congress of his consent for the record. The President's signature alone authoritatively communicates his approbation. Thus it is only by signing a bill that the President can turn it into a law. ${ }^{28}$

${ }^{26}$ Id. at 377.

${ }^{27}$ La Abra, at 454.

${ }^{28}$ Lawmaking by approval of the President is to be distinguished from lawmaking absent the President's veto. (See the third means by which a bill become law described in Part I above.) The Art. 1, §7 provision that "If any Bill shall not be returned by the President within ten Days (Sundays excepted) after it shall have been presented to him, the Same shall be a Law, in like Manner as if he had signed it," is not so much a prescription for lawmaking as an explanation of the legal effect the failure of the President to take action. As one scholar put it, "[t]he Constitution presents the President with two basic choices: to sign or veto a bill. While the Constitution does mention the possibility of the President 
Since it is the President's signature, and not his mere approval, that gives a bill the force of law, it is puzzling that the Nielson Memorandum and a 2011 Office of Legal Counsel memorandum on electronic presentment ${ }^{29}$ characterize the act of signature as a ministerial function on the part of the President. The Supreme Court has explained, "[a] ministerial duty. . . is one in respect to which nothing is left to discretion. It is a simple, definite duty, arising under conditions admitted or proved to exist, and imposed by law."30 The President's duty of signature is indeed imposed by law - by the Constitution of the United States, no less - but it cannot possibly be characterized as a duty that leaves nothing to discretion. While the President's approbation of a bill and his signature thereof are separate acts, only the President's signature gives effect to his approbation. Not just any expression of approbation will do when it comes to the enactment by the President of a law. ${ }^{31}$ Thus the Cedarbaum Memorandum was only half correct in noting that signature "is an external manifestation of internal assent, and Article I, Section 7 plainly requires the outward manifestation in addition to the internal assent when it states: 'If [the President] approve [a bill] he shall sign it." 32 But as La Abra established, because the President's approbation is meaningless absent his signature, it is not quite so easy to separate the discretionary from ministerial elements from the act of signing a bill.

This may, of course, be why over the course of more than two hundred years, at no time has a proxy signature been utilized to sign a bill into law until President Obama attempted to do so in May 2011.

\section{The Presence Requirement for Proxy Signatures}

The presence requirement for proxy signatures first appears in the Statute of Frauds of 1677, whose purpose was the "prevention of many fraudulent Practices which are commonly endeavoured to be upheld by Perjury and Subornation of Perjury". The exact text is as follows (spelling modernized):

not signing a bill, it does so not to give the President an opportunity to avoid taking responsibility for a bill, but instead to specify the legal effects of the President failing, due to oversight or intention, to exercise his powers under the Constitution." Michael B. Rappaport, The Unconstitutionality of "Signing and Not-Enforcing”, 16 WM. \& MARY BILL RTS. J. 122 (2007), 123 n. 33. Assuming the unconstitutionality of President Obama's absentee signature by proxy of the extension of the three provisions of the FISA Act, the extension will nevertheless have become valid law under this third approach to lawmaking.

${ }^{29}$ Whether Bills May be Presented by Congress and Returned by the President by Electronic Means, Memorandum Opinion for the Counsel to the President from Jonathan G. Cedarbaum, p.2 (May 3, 2011) [hereinafter Cedarbaum Memorandum].

${ }^{30}$ Mississippi v. Johnson, 17 U.S. 475, 498 (1867).

${ }^{31}$ See La Abra, note 13.

${ }^{32}$ Cedarbaum Memorandum, at 9. 
And be it further enacted by the authority aforesaid That from and after the said four and twentieth day of June all Devises and Bequests of any Lands or Tenements deviseable either by force of the Statute of Wills or by this Statute or by force of the Custom of Kent of the Customs if any Burrough or any other particular Custom shall be in Writing and signed by the party so devising the same or by some other person in his presence (emphasis added) and by his express directions and shall be attested and subscribed in the presence of the said Devisor by three or four credible Witnesses or else they shall be utterly void and of none effect. $^{33}$

The Wills Act of 1837 added to the requirements for the execution of wills:

No will shall be valid unless-

(a) it is in writing, and signed by the testator, or by some other person in his presence (emphasis added) and by his direction; and

(b) it appears that the testator intended by his signature to give effect to the will; and

(c) the signature is made or acknowledged by the testator in the presence of two or more witnesses present at the same time; and

(d) each witness either -

(i) attests and signs the will; or

(ii) acknowledges his signature, in the presence of the testator (but not necessarily in the presence of any other witness),

but no form of attestation shall be necessary. ${ }^{34}$

${ }^{33} 29$ Car. 2 , c. $3 . \S 5$.

${ }^{34} 1$ Vict. c. $26 \S 9$ (available at http://www.legislation.gov.uk/ukpga/Will4and1Vict/7/26/section/9). 
This very large, very developed and time-honored body of law - the law of wills - is the appropriate lens in which to view the requirements for a valid proxy signature. The Nielson Memorandum recognizes this implicitly in its heavy reliance on the law of wills to legitimize proxy signatures.

This presence requirement for proxy signatures endures to modern times. The Uniform Probate Code ("UPC") § 2-502, for example, requires the following:

(a) [An attested] will must be:

(1) in writing;

(2) signed by the testator or in the testator's name

by some other individual in the testator's conscious

presence (emphasis added) and by the testator's

direction; and

(3) signed by at least two individuals, each of

whom signed within a reasonable time after he [or

she] witnessed either the signing of the will as

described in paragraph (2) or the testator's

acknowledgment of that signature or

acknowledgment of the will. ${ }^{35}$

Oddly, all the cases cited in the comment to UPC § 2-502 concern the presence of witnesses to the signature of the will and not the presence of the testator herself when someone signs on her behalf at her instruction. ${ }^{36}$ The

\footnotetext{
${ }^{35}$ Uniform Probate Code $§ 2-502(\mathrm{a})(2)$; see also 79 Am. Jur. 2d Wills $§ 215$; see e.g., In re Estate of Sky Dancer, 13 P.3d 1231 (Colo. Ct. App. 2000); Matter of Guardianship and Conservatorship of Slemp, 11 Kan. App. 2d 156, 717 P.2d 519 (1986).

${ }^{36}$ The comment to UPC $§ 2-502$ explains:
}

Under subsection (a)(2), the testator must sign the will or some other individual must sign the testator's name in the testator's presence and by the testator's direction. If the latter procedure is followed, and someone else signs the testator's name, the so-called "conscious presence" test is codified, under which a signing is sufficient if it was done in the testator's conscious presence, i.e., within the range of the testator's senses such as hearing; the signing need not have occurred within the testator's line of sight. For application of the "consciouspresence" test, see Cunningham v. Cunningham, 80 Minn. 180, 83 N.W. 58 (1900) (conscious-presence requirement held satisfied where "the signing was within the sound of the testator's voice; he knew what was being done ..."); Healy v. Bartless, 73 N.H. 110, 59 A. 617 (1904) (individuals are in the decedent's conscious presence "whenever they are so near at hand that he is conscious of where they 
presence requirement for a proxy signature is so unequivocally accepted in the law of wills ${ }^{37}$ that it is not litigated very much. This is borne out by the scarcity of case law. Nevertheless, the test for the presence requirement ("conscious presence") is the same for each, so looking at the purpose of the presence requirement for witnesses is instructive. For example, one court explained the purpose of the presence requirement (as far as witnesses are concerned) as follows: "The object of the provision of the statute that the witnesses shall sign in the presence of the testator, is to prevent substitution and fraud upon him.",38

The Restatement also requires the presence of the proxy.

n. Signature by another. The testator need not sign the will himself or herself. The statutes allow someone else to sign the testator's name for the testator, if the testator directed the other person to sign the testator's name and if the other person acted in the testator's presence. In determining whether the person signed in the testator's presence, this Restatement adopts and the UPC codifies the consciouspresence test and rejects the line-of-vision test (see Comment $p$ ). ${ }^{39}$

An example of the proxy presence requirement appears in a leading wills law textbook:

Arthur spent weeks drafting a complicated will for Maria,

are and of what they are doing, through any of his senses, and where he can readily see them if he is so disposed."); Demaris' Estate, 166 Or. 36, 110 P.2d 571 (1941) ("[W]e do not believe that sight is the only test of presence. We are convinced that any of the senses that a testator possesses, which enable him to know whether another is near at hand and what he is doing, may be employed by him in determining whether [an individual is] in his [conscious] presence ... ").

${ }^{37}$ In Miller v. Miller, 96 Miss. 526 (1910), the Supreme Court of Mississippi had to consider whether a will executed by an illiterate man was valid. The testator had someone else write the will. The testator then had a witness read the document to him and sign the testator's name to it. The issue before the court, however, was not whether the proxy's signature was valid in light of the testator's inability to read the will, but rather whether the witnesses' signatures were valid. That is, the court took it as a given that even an illiterate could authorize a proxy's signature as long as that proxy was in the presence of the testator. See also Sheehan v. Kearney, 82 Miss. 688 (1903) ("Any signature or mark signed by the testator, or by another in his presence and at his express direction, to the will, as and for his completed signature, and acknowledged and adopted by him as such at the time, in the presence of the subscribing witnesses, is a sufficient signing").

${ }^{38}$ Mandeville v. Parker, 31 NJ Eq. 242, 252 (1879). For a lengthy discussion of “conscious presence" see also Dubach v. Jolly, 279 Ill. 530 (1917).

${ }^{39}$ Restatement, Third, of Property (Wills and Other Donative Transfers) § 3.1, comm. n (1998). 
one of his most wealthy and influential clients. Arthur received a telephone call from Maria while she was in flight to Europe. She explained she was running behind schedule and was not able to make it to Arthur's office to sign the will as she had planned. She then stated, "I hereby direct you to sign my will for me." Arthur complied. Is Maria's will valid?

Explanation. Courts typically hold that the testator need not actually see the proxy make the signature. Instead, the testator must be in a position where the testator could see or make use of the testator's other senses [if, for example the testator were blind] to determine what is happening. Maria's will is unlikely to be valid because Maria could not see or use her other senses to determine whether Arthur actually signed the appropriate document. ${ }^{40}$

The overarching aim of statutes governing the formal requirements of will execution was stated well in a New York case: "The formalities prescribed by the statute are safeguards thrown around the testator to prevent fraud and imposition." ${ }^{, 41}$ Thus the challenges one sees to wills signed by proxy are not rooted in arguments about the formal signing requirements but in arguments of fraud and undue influence. ${ }^{42}$

Avoidance of fraud, then, is consistently fixed as the purpose of the presence requirement, something that should be of the utmost importance in Presidential proxy signatures of bills into laws. Born of fraud prevention, this entire body of law has been consistent in its presence requirement, and was very well established at the time of the Constitution's ratification and beyond.

\footnotetext{
${ }^{40}$ Wills, Trusts, and Estates, Gerry W. Beyer, 87 (4th ed. 2007).

${ }^{41}$ In re Mackay's Will, 110 NY 611, 615 (1888). This language was also quoted in In re Will of Heaney, 347 NYS 2d 922, 923 (1973).

${ }^{42}$ One example of this is an Oregon case that held a proxy's signature of a blind man's will in the presence of the blind testator was valid. In re Pickett's Will, 49 Ore. 127 (1907). The court applied the Oregon statute establishing a presence requirement for the proxy, holding that the formal requirements of the statute were met. It further noted that the court had every reason to believe from the evidence presented that the testator was of sound mind at the time the will was signed. In fact, the will was challenged not because the claimants thought it could not be executed through the use of a proxy, but because they believed the proxy wielded undue influence over the testator.
} 
III. The Nielson Memorandum and the Presence Requirement

The Nielson Memorandum describes multiple prior legal opinions indicating that the President could not use a non-presence proxy to sign legislation. The following, taken from the House Letter, summarize these prior opinions:

- "See Rehnquist Letter at 2 (concluding that 'with the exception of signing bills passed by Congress, there is no legal impediment to the delegation of the act of signing and that the question of which documents the President should personally sign is largely one of propriety rather than of law') (emphasis added)"

- "Scalia Memorandum at 1 (citing Rehnquist Memorandum and stating that " $[\mathrm{t}] \mathrm{he}$ signing of bills passed by the Congress is one exception which may require the President's personal signature') (emphasis added)"

- "Memorandum to Files from Ralph W. Tarr, Deputy Assistant Attorney General, Office of Legal Counsel, Re: Presidential Signing of Bankruptcy Extension Act at 9-10 (June 13, 1984) ('Tarr Memorandum') ('We therefore concluded that it was necessary for the President physically to sign the bill in order for it to become a law.')"

- "Wilkey Memorandum at 10 ('a bill would seem to present an a fortiori case in which under the Constitutional provision the signification of the President's approval requires an exercise of personal discretion and therefore cannot be delegated')"

- "Rehnquist Memorandum at 2 ('the requirement for the President's signature as well as his decision approving a bill would appear to be non-delegable')"

- "Indeed, on at least two occasions, a bill was flown halfway around the world, on the advice of this Office, so that the President could personally affix his signature to it. See Tarr Memorandum at 9 (China) see also Memorandum to File from Jeffrey P. Singdahlsen, Attorney-Adviser, Office of Legal Counsel, Re: Preliminary Advice and Consideration Regarding Proposal to Fax Continuing Resolution to the President While He Was Abroad at I (Dec. 22, 1999) (Turkey)., ${ }^{43}$

\footnotetext{
${ }^{43}$ House Letter, supra note 10 at 25-26.
} 
So, the Nielson Memorandum ignores the numerous prior executive branch legal opinions concluding that the President may not have a non-presence proxy sign legislation.

Incredibly, the Nielson Memorandum concedes that the bulk of prior law addressing the issue of allowing someone else to sign on behalf of another emphatically states that the person signing has to be in the presence of the principal. Indeed, not taking into account footnote 11 (to be discussed below), the Nielson Memorandum cites twenty-two sources confirming that presence is required of a proxy signature or seal! Here are the twenty-two sources:

Even where the law required authorization under seal, however, the principle of signatures permitted one validly to sign or seal a document, in the absence of such formal authorization, by directing another to affix one's name or seal to the document in one's presence. See Ball $v$. Dunsterville, 100 Eng. Rep. 1038, 1039, 4 Term Rep. 313, 314 (K.B. 1791) ("The Court were clearly of opinion that there was no ground for the objection; that no particular mode of delivery was necessary, for that it was sufficient if the party, executing a deed, treated it as his own. And they relied principally on this deed having been executed by one defendant for himself and the other in the presence of that other."); Simonds v. Ludlow, 2 Cai. Cas. 1 (N.Y. Sup. Ct. 1805) (similar, citing Lord Lovelace's Case and Ball); Hanford v. McNair, 9 Wend. 54, 56 (N.Y. Sup. Ct. 1832) ("An agent cannot bind his principal by deed, unless he has authority by deed so to do. The only exception to the rule that the authority to execute a deed must be by deed, is where the agent or attorney affixes the seal of the principal in his presence and by his direction."); Rex v. Longnor, 110 Eng. Rep. 599, 600, 4 B. \& A. 647, 649 (K.B. 1833) (Littledale, J.) (upholding the validity of a deed where two principals "met for the purpose of executing it, [and] their names, by their authority, were written opposite to two of the seals"); cf. Mackay v. Bloodgood, 9 Johns. 285 (N.Y. Sup. Ct. 1812) ("In the present case, one of the defendants sealed the bond, with one seal, for himself and his partner, with the consent of his partner, and after the partner had seen and approved of the bond, and while he was about the store, at the time of the execution. This evidence was sufficient to carry the cause to the jury, and to justify them in finding it the deed of both." );

\footnotetext{
${ }^{44}$ Nielson Memorandum at 9.
} 
Courts based this rule on the general principle that "what a person does in the presence of another, in his name and by his direction, is the act of the latter, as if done exclusively in his own person." Kime v. Brooks, 31 N.C. 218, 220 (1848); see also Kidder v. Prescott, 24 N.H. 263 (1851) ("an act done by one in the presence and under the control of another, for that other, is regarded not as the exercise of a delegated authority, but as the personal act of the party in whose behalf it was performed"); Gardner v. Gardner, 59 Mass. 483, 484 (1850) ("The execution of the deed is objected to, on the ground, that when a deed is executed by an agent or attorney, the authority to do so must be an authority of as high a nature, derived from an instrument under the seal of the grantor. This is a good rule of law, but it does not apply to the present case. The name being written by another hand, in the presence of the grantor, and at her request, is her act."); ${ }^{45}$

As Justice Story explained,

[A]lthough a person cannot ordinarily sign a deed for and as the agent of another, without an authority given to him under seal; yet this is true only in the absence of the principal; for if the principal is present, and verbally or impliedly authorizes the agent to fix his name to the deed, it becomes the deed of the principal; and it is deemed, to all intents and purposes, as binding upon him, as if he had personally sealed and executed it. The distinction may seem nice and refined; but it proceeds upon the ground, that where the principal is present, the act of signing and sealing is to be deemed his personal act, as much as if he held the pen, and another person guided his hand and pressed it on the seal.

Story on Agency $\S 51 .^{46}$

A similar principle was expressly incorporated in the provision of the Statute of Frauds governing wills, which required that "all devises and bequests of any lands ...

\footnotetext{
${ }^{45} I d$. at 10.
}

${ }^{46} \mathrm{Id}$. 
shall be in writing, and signed by the party so devising the same, or by some other person in his presence and by his express directions, and shall be attested and subscribed in the presence of the said devisor by 3 or 4 credible witnesses." 29 Car. II. c. 3; see also Starr v. Starr, 2 Root 303 (Conn. Super. 1795) (discussing the statutory requirements); Ford v. Ford, 26 Tenn. 92 (1846) (same);

Consistent with the statutory language and the principle of signatures, courts upheld wills signed in the testator's name and presence by another. See, e.g., Cochran's Will, $6 \mathrm{Ky}$. 491, 499 (1814) ("The will was written by David Cochran, in the absence of all other persons except the testator. The name of the testator was signed by D. Cochran - he proves that it was done under the direction of the testator. The subscribing witnesses all prove the acknowledgment of the testator that this instrument was his will, and in his presence attested the same. This is a substantial compliance with the law."); Pate's Administrator v. Joe, 26 Ky. 113, 113 (1829) ("That testator's name was signed by his directions, and that witnesses subscribed their names in his presence, may be established by circumstantial evidence."), ${ }^{48}$

In addition, courts held that attesting witnesses could satisfy the statutory requirement that they "subscribe their names" to the will by directing that their signature be affixed to the will by another in their presence on the ground that, consistent with the principle of signatures, such a signing "should . . . , for every purpose contemplated by the law, be regarded as their own act, as much so as if it had been a deed to which they were subscribed, or as if their hands had been held and guided by another." Upchurch v. Upchurch, 55 Ky. 102, 113 (1855); ${ }^{49}$

Thus, for example, in reliance on the well established rule that "the name of a party affixed to an instrument by his direction, and in his presence, is affixed by himself; whether he in fact puts his hand upon the pen or not," it was held in Hanson v. Rowe, 26 N.H. 327 (1853), that where "[t]he sign of the magistrate was placed upon the writ, by a mechanical act performed in his presence and under his immediate direction and inspection," it was "to every legal intent as much his sign manual as if his own

\footnotetext{
${ }^{47}$ Id.

${ }^{48}$ Id.

${ }^{49} I d$. at $10-11$.
} 
hand had guided the pen which traced it." Id. at 329; see also Andover v. Grafton, 7 N.H. 298, 305 (1834) ("Had the selectman who signed the note, placed with his own name that of the other selectman who authorized him to settle the account and give a note, perhaps the evidence respecting the authority might have been sufficient to have rendered it valid, as it would then have purported to carry on its face evidence that it was the act of the town, by a majority of the selectmen; but even in that case it would deserve consideration, whether authority to do this could be delegated, and whether it could be legally done unless the other selectman was present, and assenting at the time of the execution of the paper.");,

And in a somewhat later case, in a context very similar to that which we consider here, the Supreme Court of the State of Missouri held that the mayor of Kansas City could approve an ordinance passed by the city counsel by directing his secretary to affix the mayor's signature to the ordinance in his presence. Porter v. Boyd Paving \& Construction Co., 214 Mo. 1 (1908). The city's charter paralleled Article I, Section 7, providing that ordinances passed by the city counsel "shall be "presented to the mayor. If the mayor approve any ordinance he shall sign it; if not he shall return it to the city clerk with his objection, and the city clerk shall at the next session of the house in which it originated return it to such house." $I d$. at $10 .{ }^{51}$

Indeed, similar principles may have governed the manner in which the King of England approved bills passed by Parliament. As Blackstone explains, the King could assent to a bill either by signing it with his own hand or by directing the clerk of Parliament to manifest the King's assent in the presence of the King and Parliament. See 1 William Blackstone, Commentaries on the Laws of England $* 184-85 ;^{52}$

For example, in 1824 Attorney General Wirt addressed the question " $[w]$ hether, in cases in which the law requires that public documents should be signed by the Secretary of the Treasury, that officer having been rendered by sickness unable to write his name in the usual manner, may impress his name by the use of a stamp or copperplate, instead of pen and ink; and whether instruments so signed are valid in

${ }^{50} I d$. at 11.

${ }^{51} I d$.

${ }^{52} I d$. 
law." Signature of the Secretary of the Treasury, $1 \mathrm{Op}$. Att'y Gen. 670, 673-74 (1824). "[P]roceed[ing] upon the postulate that the Secretary has not been so far disabled by disease but that he is capable of seeing what is done, so that one paper cannot be passed upon him for another," id. at 674, Attorney General Wirt concluded:

[I]f [the Secretary] keep the stamp or copperplate in his own possession, and either apply it himself, or cause it to be applied by another in his presence, and by his authority, I am of opinion that the instrument is as valid, in strict law, as if he had written his name with a pen. It might otherwise happen that the public might lose the services of an able officer, from a mere temporary disability in his right hand.

Id. at $673-74 ;^{53}$

If he were accustomed to sign his name by a stamp rather than with pen and ink there can be no question that he might authorize this stamp to be affixed in his presence by another person in his behalf." citing Signing Certificate Attached to Farm Loan Bonds, 31 Op. Att'y Gen. 146, 147148 (1917). ${ }^{54}$

These citations, contained in the Nielson Memorandum itself, unambiguously make the case that presence is required for a proxy signature.

This brings us to the Achilles' heel of the Nielson Memorandum, which the Office of Legal Counsel conveniently buries in a footnote. ${ }^{55}$ Footnote 11 concedes this Article's main point straight away: "[T]he principle of signatures generally required the principal's presence for his signature validly to be affixed to a document by another person otherwise lacking authority to act on the principal's behalf ..." statement of the law, footnote 11 states a "belief" wholly incommensurate with the law:

${ }^{53} I d$. at 12.

${ }^{54} I d$. at 13.

${ }^{55}$ Nielson Memorandum at 20, fn 11. As my Constitutional Law I Professor Roy A. Schotland used to say while slamming his fist to the table after one of his students failed to know the answer to a question: "Dammit! Always read the footnotes: that's where the good stuff is hiding!"

${ }^{56} \mathrm{Id}$. 
we do not believe that [the] inability of the President to delegate the decision whether to approve and sign a bill means that his presence is required when his signature is affixed to a bill he has approved and decided to sign, so long as the person affixing the President's signature to the bill has been properly and specifically authorized to perform that ministerial act. ${ }^{57}$

Footnote 11 then attempts to justify the abandonment of the centuries-old presence requirement, claiming,: "The purpose of the presence requirement appears to have been to provide a principal with control over acts done in his name in the absence of some other valid grant of authority that would otherwise constrain his agent." ${ }^{, 58}$ (This is inaccurate, of course. As this Article has clearly demonstrated, the purpose of the presence requirement is the prevention of fraud and undue influence.) The Nielson Memorandum then cherry-picks an 1848 North Carolina case in support of this proposition.

See, e.g., Kime v. Brooks, 31 N.C. 218, 220 (1848) ("what a person does in the presence of another, in his name and by his direction, is the act of the latter, as if done exclusively in his own person; but that what is done out of his presence, though by his direction and in his name, cannot in law be considered an act in propria persona, ${ }^{59}$ but one done by authority"); id. at 221 (agent's act of signing, sealing, and delivering of deed was not in principal's physical presence and could not be said to be the principal's act 'in that he saw or knew or could know of his own knowledge, that [the agent] was in fact doing what he directed her; but it rested on his confidence, that she would pursue his directions, and in her testimony that she did pursue them').

This language barely supports the memorandum's argument, much less undermines the applicability of the presence requirement. The citation does little more than offer a crude distinction between a proxy and an agent. Footnote 11 then states:

That requirement should not apply, however, when a principal properly and specifically authorizes a subordinate to affix the principal's signature to a document. Accordingly, as noted above, the Department has properly substituted specific authorization for presence in situations where an executive officer retains the decision-making function associated with a signature requirement but directs

\footnotetext{
${ }^{57}$ Id.

${ }^{58} \mathrm{Id}$.

59 “In one's own person.” Black's Law dictionary ( $9^{\text {th }}$ ed. 2009).
} 
another to perform the manual act of affixing the officer's signature. ${ }^{60}$

This bold statement runs counter to logic and counter to the body of law that has existed since the Statute of Frauds first defined a category of highvalue transactions, including the execution of wills, that would be protected from fraud by formal legal requirements. (The Nielson Memorandum uses six cites to the law of wills to support its contention that proxy signatures are allowed for Presidential signatures of legislation. Footnote 11 then ignores this body of law completely.) "Specific authorization" cannot substitute for presence. Fraud in the execution of documents can too easily occur without the presence of the principal. This requirement must be maintained for highvalue transactions both as a matter of policy and as a matter of constitutional interpretation. As to the latter, the presence requirement was firmly in place both at common law and in statutes at the time that Article I was drafted and ratified.

As further justification for the argument that presence is not required, footnote 11 cites as follows: "See, e.g., Signing Certificate Attached to Farm Loan Bonds, 31 Op. Att'y Gen. at 147-48; Affixing Facsimile Signatures to Orders, 31 Op. Att'y Gen. at 351; Wheat Memorandum at 9; Rankin Memorandum at 2-3." ${ }^{\prime}$ In sum, then, the Nielson Memorandum rests its entire argument on two Attorney General opinions, one unpublished memorandum of the Office of the Solicitor General, and one unpublished memorandum of the Office of Legal Counsel. The subjects of these opinions are signatures on certificates relating to farm loan bonds, signatures on military orders, signatures for the appointment of Postmasters (the subject of the Wheat Memorandum), and signatures for the appointment of Marshals (the subject of the Rankin Memorandum). None of the signatures discussed in these memoranda require a Presidential signature that is constitutionally mandated. The memoranda dealing with them are self-serving executive branch opinions citing no case law and positing no constitutional interpretations that would be relevant to a constitutionally-mandated Presidential signature. The Nielson Memorandum is perhaps the most selfserving of them all, as it gives shabby treatment to one of the highest-value transactions entrusted to the Executive: lawmaking itself. Footnote 11 is but a flimsy two of clubs card that is attempting to hold up the rest of the deck. ${ }^{62}$

\footnotetext{
${ }^{60}$ Nielson Memorandum at 20, fn 11.

${ }^{61} I d$.

${ }^{62}$ Note finally that the Nielson Memorandum also makes great hay of agent/principal concepts, but an agent cannot sign high-value documents such as a will on behalf of a principal even under the broadest durable power of attorney and even in the principle's presence. See, e.g., Restatement (Second) of Agency $\S 17$, cmt. b ("The making of affidavits as to knowledge and the execution of wills are illustrations of acts commonly required by statute to be done personally").
} 


\section{Potential Consequences of Unconstitutional Non-Presence Proxy Signings}

The Constitution provides:

If any Bill shall not be returned by the President within ten Days (Sundays excepted) after it shall have been presented to him, the Same shall be a Law, in like Manner as if he had signed it, unless the Congress by their Adjournment prevent its Return, in which Case it shall not be a law." 63

It takes an affirmative veto, or the adjournment of the Congressional session before ten days (not including Sundays) elapse (a so-called "pocket veto"), to keep a bill from becoming a law.

Congress approved the extension (until June 1,2015) of the amendments to FISA on May 26, 2011. As applied here, then, excluding Sundays, ten days later would be June 7, 2011. These three provisions originally expired at midnight on May 26, 2011. Assuming that the use of the autopen was unconstitutional and thus a void act, then it is as if the President had taken no action in the ten-day period, neither signing nor vetoing the renewal bill. Since both houses of Congress were in session in June 2011, the renewal bill has an effective date of June 8, 2011. There were, then, twelve days when neither the old provisions nor their replacements were valid.

The legislation extended by four years three sections of FISA: (1) socalled roving wiretaps; ${ }^{64}$ (2) the library records provision (searches of business records); ${ }^{65}$ and (3) lone wolf surveillance (individuals suspected of terrorist activities who are not known to be connected to terrorist organizations). ${ }^{66}$ Fortunately, these provisions had grandfather clauses permitting them "to remain effective with respect to investigations that began, or potential offenses that took place, before the sunset date."67 Therefore, as applied to this particular piece of legislation, the gap in the provisions' effectiveness does not seem to be problematic except for investigations and roving wiretaps beginning in the twelve-day gap period,

\footnotetext{
${ }^{63}$ U.S. Const. Article I, Section 7.

${ }^{64}$ Uniting and Strengthening America by Providing Appropriate Tools Required to Intercept and Obstruct Terrorism (USA PATRIOT) Act of 2001, P.L. 107-56 206 (2001), codified at 50 U.S.C. $\S 1805(\mathrm{c})(2)(B)(2008)$.

${ }^{65} I d$. at $\S 215$, codified at 50 U.S.C. $\$ \S 1861-2$ (2008).

${ }^{66}$ Intelligence Reform and Terrorism Prevention Act, P.L. 108-458 § 6001(a) (2004), codified at 50 U.S.C. $\S 1801(b)(1)(C)$ (2008).

${ }^{67}$ Amendments to the Foreign Intelligence Surveillance Act (FISA) Extended Until June 1, 2015, Congressional Research Service (June 16, 2011). It is not clear why, then, the White House felt it of utmost importance to not have a lapse of these three components of the Patriot Act. The White House assistant press secretary, Nick Shapiro, expressed the angst this way: "Failure to sign this legislation poses a significant risk to U.S. national security." New York Times, supra note 3.
} 
which would be illegal even now because they were never properly authorized. Law enforcement agencies, for example, should check for any roving wiretaps that were started during this twelve-day period and get them reauthorized.

However, non-presence proxy signature certainly could be more problematic for the renewal of other laws. Since most laws do not contain grandfather clauses like those in the PATRIOT Act, the use of the nonpresence autopen (or human proxy) to sign legislation could still be a significant issue in the future. Taking the roving wiretaps provision as an example, absent the grandfathering language, the lapse would have meant that the roving wiretaps authorized under this provision were illegal during this period. This would have rendered any evidence gathered during this period, or likely any evidence flowing from the fruit of its tree, unusable by a prosecutor. It also would have meant that, because of the disruption, government agents would have needed to obtain new warrants for any roving wiretaps that were ongoing as of May 26, 2011. Since the government would not have known that they needed to obtain new warrants, they likely would not have done so. Therefore, the roving wiretaps that were in place only under the authority of the original provision would still, to this day, not be lawful.

One can also easily imagine that Congress might not be in session when the ten-day period (not counting Sundays) expires. Very often, there is a hurried push at the end of Congressional sessions to get legislation passed. Many acts, then, are sent to the President for signature just as Congress is adjourning. This would, of course, mean that a non-presence autopen or human proxy signature would be tantamount to a veto by the President.

While beyond the scope of this Article, the solution to the presence requirement does not, under current law, rest in having a copy of the original bill presented by Congress sent to the President via electronic means (such as facsimile or scanned and e-mailed) to have the President sign the copy personally. Federal law requires that an enrolled bill, that is, one that has passed both chambers of Congress, be printed on parchment or paper "of suitable quality" and "sent" to the President. ${ }^{68}$ As the President's Office of Legal Counsel admitted in the Cedarbaum Memorandum, electronic presentment and return is not the most natural reading of the law. ${ }^{69}$ The Cedarbaum Memorandum states in summary:

In light of the novelty of electronic presentment and return, and the need to ensure that the President and Congress - as well as the public - share a common understanding of the

\footnotetext{
${ }^{68} 1$ U.S.C. $\$ \$ 106 \& 107$.

${ }^{69}$ Cedarbaum Memorandum at 2 ("We think those statutory directives could be read as encompassing electronic transmission, but that is not necessarily the most natural reading.").
} 
means by which these fundamental steps in the lawmaking process may be carried out, we recommend that, before electronic presentment and return might be used, 1 U.S.C. $\S \S 106,106 \mathrm{a}$, and 107 be amended to provide expressly for the permissibility of electronic presentment and that the President and Congress reach an agreement, whether by statute or other means, concerning the permissibility of electronic return of bills. ${ }^{70}$

Even if federal law is changed to allow for electronic presentment and return, there are strong policy ${ }^{71}$ and constitutional arguments against allowing electronic presentment and return, many of which are captured in the Cedarbaum Memorandum. Indeed, the Cedarbaum Memorandum concedes that "[a]s far as we are aware, [it] has been Congress's unbroken practice" to have House and Senate representatives sign one paper bill that the President signs. ${ }^{72}$ The Cedarbaum Memorandum actually cites two prior Office of Legal Counsel memoranda that conclude that the Constitution does not permit electronic presentment and return.

We have in the past advised that this provision requires the President to sign the enrolled bill actually signed by the presiding officers of the House and Senate. See Memorandum to the Files from Ralph W. Tarr, Deputy Assistant Attorney General, Office of Legal Counsel, Re: Presidential Signing of Bankruptcy Extension Act at 10-11 (June 13, 1984) (" $[\mathrm{t}] \mathrm{he}$ Constitution appears to require that the President sign the actual enrolled bill presented to him, not a copy or facsimile thereof") ("Tarr Memo"); see also Memorandum to the Files from Jeffrey P. Singdahlsen, Attorney-Adviser, Office of Legal Counsel, $R e$ : Preliminary Advice and Consideration Regarding Proposal to Fax Continuing Resolution to the President While He Was Abroad at 1-2 (Dec. 22, 1999) ("Singdahlsen Memo"). We did so in part based on the provision's wording and in part based on the unbroken practice of presenting the copy actually signed by the presiding officers. ${ }^{73}$

Having all three original signatures on a law makes for an important

${ }^{70} I d$.

${ }^{71}$ Note, for example, that the federal Electronic Signatures Act, which provides that "an electronic signature satisfies the law" as to contracts, is inapplicable to wills. 15 U.S.C. $\S \S 7001,7003(a)(1)$. Similarly, the National Conference of Commissioners on Uniform State Laws were aware of the potential for fraud and other abuse in the will context and included a provision specifically excluding the use of an electronic signature to execute a testamentary document. Uniform Electronic Transactions Act of 1999, 7A U.S.A. 213 (2002). Similar policy reasoning should apply to the electronic presentment issue.

${ }^{72}$ Cedarbaum Memorandum at 19.

${ }^{73} \mathrm{Id}$. at 4. 
authentication and fraud-prevention mechanism.

\section{Conclusion}

The dangers of fraud and undue influence that prompted the enactment of the proxy presence requirement contained in the English Statute of Frauds almost 350 years ago continue to be of concern today, especially with advancements in technology such as the autopen. Regardless of changing technology, the safest method for avoiding fraud is the same today as hundreds of years ago: have the principal sign a document in pen or require that a proxy (whether human or autopen) do so in the presence of the principal. This practice is most relevant where the stakes are highest, be it signing wills or enacting legislation.

The state of the law surrounding proxy signatures has remained amazingly constant through both English and American history. Presence is clearly required for a proxy signature: period. This was the rock-solid law when the constitution was written. The Nielson Memorandum acknowledges this with twenty-two citations - six of which relate to the law of wills - before haphazardly attempting to explain this vast body of law away in its shoddily-crafted footnote 11.

No one seems focused on the presence requirement: not the President, nor the Republican House members who complained to the President, nor the numerous legal commentators and scholars that we have heard from since the autopen signing occurred. The use of the autopen, itself unproblematic, seems to have eclipsed the more important issue of whether the president was present when it was used.

While the consequences of this voided signature may not be great with respect to the FISA extensions, future legislation signed in this manner may not be so fortuitously crafted. By definition, if a non-presence proxy signature is affixed to a bill, then time is of the essence. When time is of the essence, the consequences of a voided signature are never greater. Since the President has roughly twelve days to sign a bill, a non-presence proxy signature could produce one of two unintended consequences. At best, it would produce a twelve-day period during which the new legislation would not be in effect. At worst, if Congress is not in session at the end of the twelve-day period, it would amount to a pocket veto. Neither case is consistent with well-ordered government.

Let the autopen episode not be a precedent for this or any other President to follow. The Constitution does not allow for shortcuts. 